\title{
FACSAPOS KAPCSOLATOK KÍSÉRLETI VIZSGÁLATA: ROSTIRÁNYÚ HÚZÁS
}

\section{EXPERIMENTAL STUDY OF CONNECTIONS WITH HARDWOOD STUDS}

\author{
Hudák József ${ }^{1}$, Literáti Zsolt ${ }^{2}$, Kovács Imre ${ }^{3}$, Radnay László ${ }^{4}$ \\ Debreceni Egyetem Müszaki Kar Épitőmérnöki Tanszék; 4028 Magyarország, \\ Debrecen, Ótemetö utca 2-4. \\ 1jhudak1991@gmail.com \\ ${ }^{2}$ zsoltliterati@gmail.com \\ 3r.kovacs.imre@gmail.com \\ ${ }^{4}$ radnaylaszlo@gmail.com
}

\begin{abstract}
Attitude change is needed in design of timber structures. Truss girder made of timber elements with small cross sections can be used on large spans. Constructing structures with the use of these prefabricated trusses reduces the need of in-site work, and makes the use of timber structures economic. Rods of truss can be connected with the use of hardwood stud. On this way all steel components can be eliminated from the truss, so it can be used in aggressive environment as well. Dowel type connection, with hard wood stud is the subject of the present research. Hardwood studs were investigated individually and also as the part of separated connections of the truss girder.
\end{abstract}

Keywords: timber structure, truss girder, hardwood stud.

\section{Összefoglalás}

Faszerkezetek tervezésében szemléletváltás szükséges. Kis keresztmetszetü fürészáruból összeállított rácsos tartószerkezetek alkalmasak nagy fesztávok áthidalására. Az így előregyártott tartószerkezeti elemek felhasználása csökkenti a helyszíni munkát, és gazdaságossá teszi a faszerkezetek alkalmazását. A rácsrudak kapcsolata keményfa-csap alkalmazásával, az acél szerkezeti elemek teljes kiiktatásával is kialakítható, így a szerkezet agresszív környezetben is alkalmazhatóvá válik. Jelen kutatás témája a facsapos kapcsolat. Kísérleteinkben facsapok, és egyes facsapos kapcsolatok teherbírását vizsgáltuk.

Kulcsszavak: faszerkezet, rácsos tartó, keményfa-csap.

\section{Bevezetés}

A facsapos rácsos tartókat több évtizede alkalmazzák Magyarországon, azonban a szerkezetek méretezési eljárása nem tisztázott, a kivitelezett szerkezetekért a gyártó vállal garanciát. Kutatásunk célja, hogy számítási modellt alkossunk a keményfacsapos kapcsolatok méretezésére, ehhez szükség volt egy kísérletsorozat kidolgozására.

A kísérleti eredmények alapján képet kaptunk a kapcsolatok tényleges teherbírá- 
sáról, viselkedéséről, valamint a keményfacsapos kapcsolatokra jellemző tönkremeneteli módokról.

\section{Facsapos technológia rövid be- mutatása}

A technológia fejlödésével a faanyagú tartószerkezetek alkalmazása egyre több területen válik lehetségessé. A hagyományos ács jellegủ szerkezeteket felváltották a síkbeli tartókból felépülő mérnöki jellegü faszerkezetek. Ezek legtöbb esetben rétegelt ragasztott tartók vagy rácsos tartók. A kis keresztmetszetủ fürészáruból összeállított rácsos tartószerkezetek alkalmasak nagy fesztávok áthidalására.

Síkbeli, faanyagú rácsos tartók kialakításának alternatív módszere a keményfacsapos szerkezetek építése. Ilyen szerkezetekben, a csomópontokban a rácsrudak kapcsolatát keményfa csapok biztosítják, esztétikus, homogén szerkezetet képezve. Az acél kötőelemek teljes kiiktatásával a szerkezet agresszív környezetben is alkalmazhatóvá válik, emellett tüzvédelmi szempontból is kedvezőbb. Az alapanyag C20 szilárdsági osztályú (az MSZ EN 140811:2005+A1:2011 szerint), felületkezelt, fenyő fürészáru. A tartószerkezet legfontosabb eleme a keményfa-csap, melynek átmérője $30 \mathrm{~mm}$ és jellemzően akácfából készül, esztergálással.

\section{Probléma megfogalmazása}

A csapos kapcsolatok kialakítása fém csapok alkalmazásával széles körben elterjedt ugyan, de nem található specifikusan keményfa csapos kapcsolatokkal foglalkozó szakirodalom. Az MSZ EN a csap típusú kapcsolatokat a Johansen által kidolgozott módszerrel vizsgálja.

$\mathrm{Az}$ MSZ EN 1995-1-1:2010 (Eurocode 5) szabvány 8 . Fejezete tárgyalja az acél kapcsolóelemes kapcsolatokat. A méretezési eljárás alapját a $\mathrm{K}$. W. Johansen [2] által leírt vizsgálat képezi. A szabvány által eloírt geometriára vonatkozó szerkesztési szabályok betartásával egy kapcsolat teherbírása függ a kapcsolóelem képlékeny nyomatéki teherbírásától, beágyazási szilárdságától és a kihúzódási szilárdságtól. A szabvány a 8.2.2-es szakaszban ismerteti a fa-fa, illetve falemez-fa kapcsolatokra vonatkozó tönkremeneteleket, és az ezekhez tartozó teherbírások meghatározását. Ezek alapján az egyszer nyírt kapcsolatokra hat, a kétszer nyírt kapcsolóelemes kapcsolatokra négy tönkremeneteli módot definiál. Az egyes tönkremeneteli módoknak megfelelö teherbírások karakterisztikus értéke meghatározható, ezek minimuma adja a kapcsolat teherbírását. Kutatómunkánk keretén belül kétszer nyírt kapcsolatokat vizsgáltunk, melyekhez tartozó, szabványban szereplö tönkremeneteleket az 1. ábra szemlélteti:

- palástnyomási tönkremenetel a szélső elemekben (1.);

- palástnyomási tönkremenetel a közbenső elemben (2.);

- kapcsolóelem hajlítási tönkremenetele, 2 képlékeny csukló kialakulása (3.);

- kapcsolóelem hajlítási tönkremenetele, 4 képlékeny csukló kialakulása (4.).

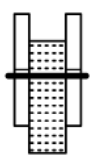

[1.]

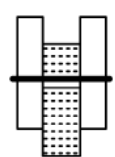

[2.]

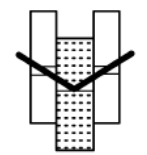

[3.]

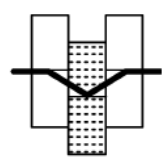

[4.]
1. ábra. Két nyirt síkú kapcsolóelemes kapcsolatok tönkremeneteli módjai [1]

A keményfa-csapos szerkezetekben a csapok jellemző átmérője $30 \mathrm{~mm}$. Ilyen nagy átmérőjű csap esetén azonban a szerkesztési szabályoknak nehéz eleget tenni. A gazdaságosan alkalmazható csaptengelyelemvég távolság $75 \mathrm{~mm}$. $15 \mathrm{~cm}$ széles deszkák és pallók kapcsolataként ez a méret alakítható ki gazdaságosan. A szabvány által elöírt minimális elemvég-távolság: $a=\max (7 d, 80 \mathrm{~mm})$, tehát $210 \mathrm{~mm}$. 
Mivel fém csapok helyett keményfacsapokat alkalmazunk, valamint nem teljesülnek a szerkesztési szabályok (csaptengely-elemvég távolság), a kísérleteink során fellépö tönkremenetelek eltértek a szabványban szereplő tönkremeneteli módoktól. Ezért a Johansen-egyenletek alkalmazásán túl további vizsgálatok szükségesek.

\section{Kutatómunka bemutatása}

A számítási modellek megalkotásához és a jellemző tönkremeneteli módok megismeréséhez kísérleti programot dolgoztunk ki. Kísérleteink célja a megvalósult szerkezetek elemeinek, kapcsolatainak modellezése, majd ezek tényleges teherbírásának meghatározása. A csomópontok teherbírását alapvetően meghatározza a keményfa csapok teherbírása, így ezeket elkülönítetten is vizsgáltuk. Kétféle vizsgálatnak vetettük alá a kapcsolóelemeket: hajlítás és nyírás [4]. Jelen cikkben a kapcsolatok húzókísérleteit tárgyaljuk.

Vizsgálatainkat a Debreceni Egyetem, Építőmérnöki Tanszékének Anyag-, és szerkezetvizsgáló laboratóriumban végeztük.

\subsection{Első húzókísérlet-sorozat}

Vizsgálataink során a kapcsolatok ragasztás nélkül lettek kialakítva. A terhelés elmozdulás-vezérelt módon történt, 0,5 $\mathrm{mm} / \mathrm{min}$ sebességgel. Az erő iránya minden esetben megegyezett a rostiránnyal. A vizsgálatokhoz tartozó kísérleti elrendezést a 2. ábra szemlélteti.

Az első kísérletsorozat célja volt, hogy képet kapjunk a kapcsolatok terhelés alatti viselkedéseiről, lehetséges tönkremenetelei módjairól. $10 \mathrm{db}$. különböző geometriai tulajdonságokkal rendelkező, egy csapos próbatestet vizsgáltunk. Változó volt a csap tengelyének az elemvégtől mért távolsága, valamint a duplázott elemek vastagsága $(2,5$ $\mathrm{cm}$ vagy $5 \mathrm{~cm}$ ). A kísérletsorozat eredményei a várakozásoknak megfelelően alakultak: növelve a csaptengely-elemvég távol- ságot, a tönkremenetel módja egyre inkább átment az alapanyag oldaláról a csap tönkremenetele felé, ezzel együtt a kapcsolat teherbírása is nött. A csap tönkremenetele magasabb teherszinten, nagyobb elemvégtávolság esetén áll elő. Ebben az esetben kevésbé viselkedik ridegen a kapcsolat, a legvégső tönkremenetelt a csap alakváltozási képességének, valamint az alapanyagba történő beágyazódásnak köszönhetően nagy alakváltozások előzik meg.

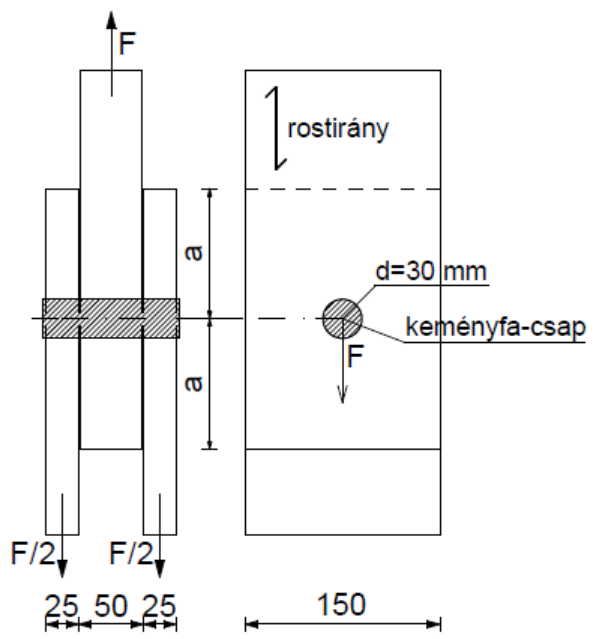

2. ábra. Húzókísérletek próbatesteinek vázlata

\subsection{Második húzókísérlet-sorozat}

A második kísérletsorozatban $15 \mathrm{db}$ egyforma, egy csapos próbatest készült. A csap tengelyének és az elem végkeresztmetszetének a távolsága $75 \mathrm{~mm}$ volt. $25 \mathrm{~mm}$ vastag duplázott elemeket alkalmaztunk. A $15 \mathrm{~cm}$ széles pallók és deszkák kapcsolataiként ez alakítható ki gazdaságosan. Minden egyes próbatest esetén a kapcsolóelem feletti alapanyag tönkremenetele jelentette a kapcsolat teherbírásának kimerülését: felhasadás vagy elnyíródás formájában.

A felhasadás jelenségét kis alakváltozások előzik meg, és kisebb teherszinten is bekövetkezhet. Tartószerkezeti szempontból ez a rideg tönkremenetel kedvezőtlen. A 
kivitelezés során fúrás elött, a csap körül az elemeket önfúró csavarokkal egymáshoz rögzítik, ez kedvezöen hathat a felhasadás bekövetkezése után. Számos esetben a felhasadás után a próbatest a repedés egyre jelentősebb megnyílása mellett, a csap feletti részek nyírási tönkremeneteléig, vagy a csap alatti rész felrepedéssel bekövetkező szétnyílásáig további terheket vett fel, ezeket a teherbírás meghatározásánál nem vesszük figyelembe.

\subsection{Harmadik húzókísérlet-sorozat}

A harmadik húzókísérlet-sorozatban a csaptengely-elemvég távolságot $75 \mathrm{~mm}$-röl 100 mm-re növeltük. Célunk az volt, hogy megfigyeljük a tönkremeneteli módok változását, beleértve a felhasadás jelenségének kialakulását megnövelt csaptengelyelemvég távolság esetén. Jorissen [3] vizsgálatai szerint a hasadást előidéző lokális repedések mindig megjelennek, az elemvég távolságtól függetlenül.

A törőerők átlagértéke $9 \%$-kal nőtt a nagyobb elemvég távolságnak köszönhetöen. A megnövelt csaptengely-elemvég távolság ellenére a felhasadás jellegű tönkremenetel itt is több alkalommal előfordult, ám az előző, $75 \mathrm{~mm}$-es sorozathoz képest magasabb teherszinten. A második kísérletsorozattal ellentétben, 5 esetben a keményfa csap kapcsolóelem tönkremenetele is bekövetkezett.

\section{Következtetések}

Kísérleteink átfogó képet adnak a keményfa-csapos kapcsolatok terhelés alatti viselkedéséről, teherbírásáról, változó geometriai feltételek esetén.
A szerkesztési szabályok be nem tartása és a faanyagú kapcsolóelem alkalmazása következtében olyan tönkremeneteli módok jelennek meg, amelyeket a szabvány nem tárgyal:

- kapcsolóelem nyírási tönkremenetel;

- alapanyag felhasadás jellegủ tönkremenetele;

- alapanyag nyírási jellegü tönkremenetele.

A szakirodalomban tárgyalt számítási módszerek alkalmazhatóságát vizsgáltuk. $\mathrm{Az}$ eddigi vizsgálatok alapján részben saját [4], részben más kutatók [2],[3] által felállított modellekkel közelíthetjük a kapcsolatok teherbírását.

Ahhoz, hogy az eljárások alkalmazhatóak legyenek, további vizsgálatokra van szükség, különös tekintettel a rideg, felhasadás jellegü tönkremenetelekre vonatkozóan.

\section{Szakirodalmi hivatkozások}

[1] MSZ - EN - 1995-1-1:2010 - Eurocode 5: Faszerkezetek tervezése, pp. 55-56.

[2] Johansen, K. W.: Theory of timber connections. International Association of Bridge and Structural Engineering, Publication, Copenhagen, 1949.I.S. Jacobs and C.P. Bean, "Fine particles, thin films and exchange anisotropy," in Magnetism, vol. III, G.T. Rado and H. Suhl, Eds. New York: Academic, 1963, pp. 271-350.

[3] Jorissen, A.: Double shear timber connections with dowel type fasteners. Ph.Dthesis; Delft University Press, Delft, The Netherlands, 1998, pp. 22-52.

[4] Hudák J., Literáti ZS., Facsapos kapcsolatok kísérleti vizsgálata, Debrecen, 2015. 